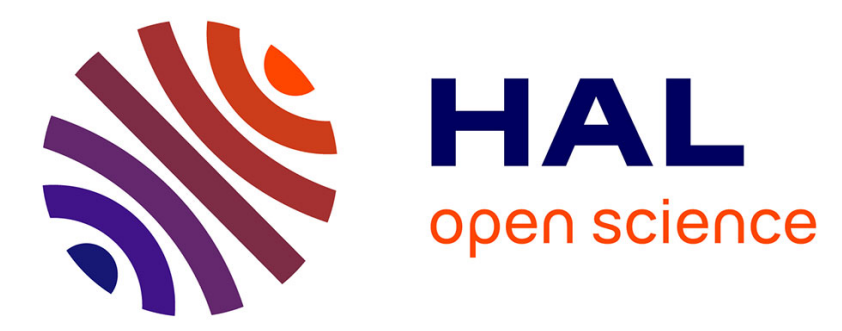

\title{
Before-After analysis of the trophic network of an experimental dumping site in the eastern part of the Bay of Seine (English Channel)
}

Jean-Philippe Pezy, Aurore Raoux, Stella Marmin, Pierre Balay, Nathalie Niquil, Jean-Claude Dauvin

\section{To cite this version:}

Jean-Philippe Pezy, Aurore Raoux, Stella Marmin, Pierre Balay, Nathalie Niquil, et al.. BeforeAfter analysis of the trophic network of an experimental dumping site in the eastern part of the Bay of Seine (English Channel). Marine Pollution Bulletin, 2017, 118 (1-2), pp.101 - 111. 10.1016/j.marpolbul.2017.02.042 . hal-01691022

\section{HAL Id: hal-01691022 https://hal.science/hal-01691022}

Submitted on 3 Jun 2019

HAL is a multi-disciplinary open access archive for the deposit and dissemination of scientific research documents, whether they are published or not. The documents may come from teaching and research institutions in France or abroad, or from public or private research centers.
L'archive ouverte pluridisciplinaire HAL, est destinée au dépôt et à la diffusion de documents scientifiques de niveau recherche, publiés ou non, émanant des établissements d'enseignement et de recherche français ou étrangers, des laboratoires publics ou privés. 


\title{
Marine Pollution Bulletin
}

Before-After analysis of the trophic network of an experimental dumping site in the eastern part of the Bay of Seine (English Channel)

\author{
Jean-Philippe Pezy ${ }^{a^{*}}$, Aurore Raoux ${ }^{a, b}$, Stella Marmin ${ }^{a}$, Pierre Balay ${ }^{c}$, Nathalie Niquil ${ }^{b}$ and \\ Jean-Claude Dauvin ${ }^{\mathrm{a}}$
}

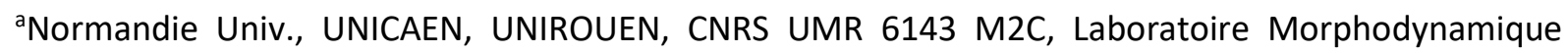
Continentale et Côtière, 24 rue des Tilleuls, 14000 Caen, France

${ }^{\text {b} N o r m a n d i e ~ U n i v ., ~ U N I C A E N, ~ U M R ~ B O R E A ~(M N H N, ~ U P M C, ~ C N R S-7208, ~ I R D-207), ~ E s p l a n a d e ~ d e ~ l a ~ P a i x, ~}$ 14032 Caen CEDEX 5, France

${ }^{c}$ Cellule de Suivi du Littoral Normand, CSLN, 53 Rue de Prony, 76600 Le Havre

*Corresponding author: jean-philippe.pezy@unicaen.fr

\section{ABSTRACT}

An experimental study was conducted to assess the physical and biological impacts of muddy fine sand dredged material dumped on a medium sand site MACHU offshore the Seine Estuary. Complementary trophic web modelling tools were applied to the MACHU ecosystem to analyse the effects of dumping operations. Results show that, after the dumping operations, the biomass of fish increased while invertebrate biomass remained relatively stable through time. Nevertheless, the biomasses of benthic invertebrates, omnivores/scavengers and predators showed some increases, while non-selective deposit feeders and filter feeders decreased. At the ecosystem level, results show that the total ecosystem activity, the ascendency and the overall omnivorous character of the food-web structure increased after dumping operations, whereas recycling subsequently decreased. Finally, the fine and medium sand habitat offshore from the Seine estuary, which undergoes regular natural physical perturbations, shows a high resilience after a short dumping phase.

Keywords: Ecopath; trophic model; Ecological Network Analysis; dredged material disposal; Bay of Seine 


\section{Introduction}

14

To enable their economic development, harbours are required to maintain their maritime access conditions. The need for dredging has resulted from increased marine transportation requirements and vessel size, and modifications in the sedimentation patterns of estuaries and rivers due to harbour and industrial developments as well as urbanization (Messieh et al., 1991; Marmin et al., 2014). As a consequence, navigation channels are regularly dredged to ensure sufficient depth for a large variety of vessels including the largest container ships. According to their low chemical hazard for the environment, dredged materials have been mainly disposed of on sea often outside marine protected areas, by overflowing during dredging, dumping in authorized zones or brought ashore for storage or treatment (Marmin et al., 2014). Deposition on land remains an alternative which is obligatory for contaminated sediment but which requires large storage spaces not used by other human activities. In the case of 'clean' sand sediment (i.e. without high \% of mud), the dredged material can be used for the creation of artificial wetland areas or beach nourishment. However, nowadays, for economic reasons, most dredged material is disposed of in coastal zones in open water (Marmin et al., 2014).

The Seine estuary is one of the main estuaries on the northwest European continental shelf and is economically important for France, due to the presence of two maritime harbours: Grand Port Maritime du Havre (GPMH) at the entrance of the estuary and the upstream Grand Port Maritime de Rouen (GPMR). The watershed of the Seine covers an area of $\sim 79,000 \mathrm{~km}^{2}$ with a population of $\sim 16$ million inhabitants, accounting for $\sim 50 \%$ of the river traffic in France, $\sim 40 \%$ of the country's economic activity and $~ 30 \%$ of its agricultural activities (Dauvin, 2006). The GPMR, which is the most important French inland harbour, is located in the freshwater part of the Seine estuary at $\sim 120 \mathrm{~km}$ from the sea. Its access is ensured by regular maintenance and permanent dredging of the navigation channel, mainly in the lower part of the Seine estuary between the Normandy Bridge and the open sea. Each year, the GPMR dredges between 4 and 4.5 million cubic meters of sediment, which is dumped on the disposal site called Kannik commissioned in 1977 in the Northern Channel of the Seine estuary (Marmin et al., 2014, 2016) (Fig. 1). Moreover, the GPMH dredges between 2 and 2.5 million cubic metres of sediment each year in the harbour basins and deposits this material in an offshore deposit zone named Octeville (Fig. 1) (Marmin et al., 2014).

The dumping of dredged material represents one of the most important problems in coastal zone management and leads to a major disturbance of the environment (Marmin et al., 2014). The type and severity of the impact of dumping of dredged material on benthic macrofauna depend on many factors: 1) the physico-chemical characteristics and the volume of sediment deposited; 2) the physical conditions of the depositional environment: water depth, sediment and hydrodynamic regime; 3) the season and the similarity between sediment of the dredging area and in the dumping area; 4) the 
contamination of dredged materials; 5) the methods of dumping; 6) the adaptation of organisms to the local sedimentary regime and 7) the structure and composition of the benthic community in the dumping area and neighbouring sites (Marmin, 2013). Furthermore, numerous studies have been conducted to investigate the effects of dumping on benthic macrofauna (for example see Van Dolah et al., 1984; Harvey et al., 1998; Roberts et al., 1998; Smith and Rule, 2001; Witt et al., 2004). In many cases, these studies focused on the structure of benthic invertebrate communities to assess the impacts and/or recovery from this activity, i.e. the resistance and resilience of benthic habitats to the stress due to the sediment deposit. Few studies dealt with the assessment of functional changes of such benthic habitats (Wilber et al., 2007; Bolam et al., 2011; Bolam, 2012; Bolam et al., 2016). In addition, dumping operations can generate negative impacts on fish eggs and larvae: i.e. Messieh et al. (1991) showed that sediment deposited on herring spawn increase egg mortality. Changes in species composition can be observed, and this has an impact on the food-web structure and functioning (Messieh et al., 1991).

Under European Union pressure, the French administration and non-governmental environmental protection organizations require that maritime harbours take account of the Integrated Coastal Zone Management (ICZM) of the Seine estuary in the context of their economic development project (Marmin et al., 2014). Among the requests, the Scientific Committee of the Seine Estuary (SCSE), which was created in 2008 to help the French State and port authorities to promote the sustainable development of the Seine estuary, has asked the GPMR to find a new sediment dumping area outside the Seine estuary.

The SCSE studies led to validation of the Machu site, composed of fine to medium sand located in the eastern part of the Bay of Seine (Marmin, 2013; Marmin et al., 2014, 2016) (Fig. 1). In 2012-2013, experimental dumping operations were carried out to better understand the impacts of the deposition of sediments from the navigation channel onto the morphosedimentary seabed and benthic habitats of the Machu site using a Before-After-Control Impact approach (Marmin, 2013; Marmin et al., 2014, 2016).

In this study, we develop a holistic view of the impact of dumping operations on ecosystem functioning through the use of trophic web modelling tools. Trophic models describe the interaction between biological compartments at different trophic levels and are based on the quantification of energy flow and matter in ecosystems. These models make use of numerical methods to characterize the emergent properties of ecosystems, by application of Ecological Network Analysis (ENA) (Ulanowicz, 1986). This type of joint analysis has been frequently applied to coastal and marine systems to assess changes in their functioning in response to environmental perturbations (Ortiz and Wolff 2002; Rybarczyk et al., 2003; Niquil et al., 2012; Tecchio et al., 2013, 2015). ENA indices have 
also been proposed as trophic descriptors of ecosystem health for the EU Marine Strategy Framework Directive (Niquil et al., 2012; Niquil et al., 2014).

Various modelling studies related to the eastern part of the Bay of Seine and the Seine estuary have been implemented over the two last decades. The structure and functioning of the Seine estuary was investigated by Rybarczyk and Elkaim (2003), who considered it as a single spatial compartment and then by Tecchio et al. $(2015 ; 2016)$, who divided it into six spatial compartments.

Assuming that dumping operations represent a stress for the ecosystem, such as other natural and anthropogenic stresses (granulate extraction, fish trawling, harbour works, etc.), we use the ENA approach here to test its efficiency in detecting functional changes of benthic habitats. Thus, this study is focused on the following objectives: 1 ) to characterize the trophic network of the Machu site before experimental deposition, 2) to determine the effect of sediment dumping on the structure of the food web, and thus 3) to evaluate the interest of the ENA approach in a context of inherently stressed environments. To address these questions, several ECOPATH models are constructed which are defined and described in the following sections.

\section{Materials and methods}

\subsection{Study area}

The Bay of Seine forms an approximate quadrilateral of $5,000 \mathrm{~km}^{2}$, with water depths never exceeding $30 \mathrm{~m}$. In this macrotidal environment (tidal ranges of up to $7.5 \mathrm{~m}$ at Le Havre), tidal currents average between 1 and 2 knots in the southern sector of the bay, and their intensity gradually diminishes towards the eastern part of the Bay of Seine (Salomon and Breton, 1991, 1993). These currents play an essential role in the distribution of sediments (Larsonneur et al., 1982) and benthic communities (Gentil and Cabioch, 1997). Lesourd (2003) provided the last map of sedimentary facies across the eastern Bay of Seine before the 'Port 2000' construction (2002-2005), and identified an offshore-inshore gradient; the offshore sediments generally consist of gravel and coarse sand, while sediments just at the mouth of the Seine Estuary, are mainly fine sand and silty/muddy fine sands. Moreover, seasonal variations in the sedimentary regime in the mouth of the macrotidal Seine estuary, are described in Lesourd et al. (2003). The most recent map of the distribution of superficial sediments in the mouth of the Seine estuary and the eastern part of the Bay of Seine shows a high diversity of facies mainly in the North Channel (Lesourd et al., 2016). A general overview shows: broad sand bars on both sides of the entry of the navigation channel; extensive development of sandy mud facies ( 25 to $75 \%$ of silt and clay); an area of muddy sand facies juxtaposing coarse sand in the shallower waters of the Bay of the Seine and the persistence of medium sand in the offshore Machu area, with a weak influence of fine particle coming from the estuary. 
The chosen Machu experimental disposal site is located in the eastern part of the Bay of Seine (Fig. 1) at a mean water depth of $\sim 20-25 \mathrm{~m}$. Two million cubic metres of dredged sediment coming from the maintenance of the navigation channel of the Seine estuary were dumped on the experimental disposal area in 2012-2013 (Marmin et al., 2016). The first million cubic metres were deposited between May $13^{\text {th }} 2012$ and December $15^{\text {th }} 2012$ on the MASED site (Fig. 1). This site corresponds to a single point forming a conical deposit equivalent to 7 months of dumping activities. A second million cubic meters of sediment was deposited between $16^{\text {th }}$ April 2012 and $21^{\text {th }}$ February 2013 on the MABIO site (Fig. 1). The dumping operations were carried out four times, corresponding to the deposition of $250000 \mathrm{~m}^{3}$ of sediment per season on rectangular area of about 100 ha (Marmin et al., 2016).

\subsection{Modelling approach}

The Ecopath with Ecosim (EwE) software suite (Polovina, 1984, Christensen and Walters, 2004, Christensen et al., 2008) is used here to model the food web at the Machu site before (2010-2011 data) and after (2013-2014) the dumping operations (spring 2012-winter 2013) to evaluate the impacts of short-term deposition on the food-web structure and functioning. The modelling suite is composed of three modules: Ecopath, which provides mass-balanced snapshot of the system, Ecosim, a timedynamic extension and Ecospace, a temporal-spatial model. Ecopath is a mass-balance (i.e. neglecting year-to-year changes in biomass compared to flows), single-solution model (i.e. returning only one value per flow), that estimates flows between a set of established trophic compartments. Each compartment is parameterized using its biomass data $\left(B, g C . \mathrm{m}^{-2}\right)$, its production to biomass ratio $(\mathrm{P} / \mathrm{B}$, year $\left.{ }^{-1}\right)$, its production to consumption ratio $\left(P / Q\right.$, year $\left.{ }^{-1}\right)$ or its consumption to biomass ratio $(Q / B$, year $\left.{ }^{-1}\right)$, and a diet matrix $\left(D_{\mathrm{ij}}\right)$ which establishes the interactions between predators and preys in the system (Christensen and Walters, 2004).

The parameterization of an Ecopath model is based on satisfying two equations. The first equation (Eq. 1) describes the production for each compartment in the system as a function of the consumption to biomass ratio $(Q / B)$ of its predators $(j)$, the fishing mortality $\left(Y_{i}, g C \cdot m^{-2}\right)$, the net migration $\left(E_{i}\right.$; emigration - immigration, year $\left.{ }^{-1}\right)$, the biomass accumulation $\left(\mathrm{BA}_{\mathrm{i}}\right.$, year $\left.{ }^{-1}\right)$ and its natural mortality $(1-$ $\mathrm{EE}_{\mathrm{i}}$ ). The Ecotrophic Efficiency $(\mathrm{EE})$ is the fraction of total production that is consumed in the system (by fishing activity or by predators). Its value can never exceed 1. (1-EEi) represents the fraction of mortality not explained by the model, such as mortality due to old age or diseases.

$$
B\left(\frac{P}{B}\right)_{i}=\sum_{j} B_{j}\left(\frac{Q}{B}\right)_{j} D C_{i j}+Y_{i}+E_{i}+B A_{i}+B_{i}\left(\frac{P}{B}\right)_{i}\left(1-E E_{i}\right)
$$

The second equation (Eq. 2) describes the energy balance within a compartment, which expresses consumption $\left(Q_{i}\right)$ as the sum of production $\left(P_{i}\right)$, respiration $\left(R_{i}, g C \cdot m^{-2}\right)$ and unassimilated food $\left(U_{i}\right)$. 
152

153

154

155

156

157

158

159

160

161

162

163

164

165

166

167

168

169

170

171

172

173

174

175

176

177

178

179

180

181

182

183

184

185

\subsection{Functional groups}

The selection and aggregation of functional groups included in the Ecopath model is based on the biological and ecological characteristics of the species or groups of species, such as their food preference, as well as on data availability. On this basis, 15 functional groups are selected (Table 1, Fig. 2), including fish, seven invertebrate groups, zooplankton, primary producers, bacteria and detritus.

\subsubsection{Fish compartments}

Fish data were collected by the Cellule de Suivi du Littoral Normand (CSLN) from bottom otter trawl surveys at night. The available data was collected from a total of 8 beam trawl campaigns carried out before the dumping operations in April, July, October 2010 and in January 2011, and then after the dumping operations in April, July, October 2013 and in January 2014. Fish were divided into 4 functional groups: piscivorous, demersal, benthic- feeding and planktivorous.

For each campaign, total biomasses in wet weight are divided by the number of individuals of each species to obtain the individual wet weight. A conversion factor of 0.35 is used to convert both wet weights into dry weights and into carbon contents (Boët et al., 1999). For each trophic compartment, the mean biomasses were calculated. $\mathrm{Q} / \mathrm{B}$ and $\mathrm{P} / \mathrm{B}$ ratios are taken from Mackinson and Daskalov (2007). The diet matrix is constructed mainly using the stomach contents given in literature data from the eastern part of the English Channel (Cachera, 2013).

\subsubsection{Invertebrates compartments}

\subsubsection{Cephalopods}

Biomass data (in kg. $\mathrm{km}^{-2}$ ) for cephalopods were also obtained from beam trawl CSLN surveys. $\mathrm{Q} / \mathrm{B}$ and $\mathrm{P} / \mathrm{B}$ ratios were taken from Sanchez and Olaso (2004). Diet compositions are compiled from the literature (De Pierrepont et al., 2005; Daly et al., 2001).

\subsubsection{Benthic invertebrates}

Benthic invertebrates were sampled with a $0.1 \mathrm{~m}^{2}$ Van Veen grab (thee replicates at each station). Before the dumping operations, the macrobenthos data were collected from the sampling of 
17 stations in 2010-2011. The Machu habitat is associated with the medium-to-fine sand Ophelia borealis community (Gentil and Cabioch, 1997), but is partially influenced by a mixing between Ophelia borealis and Abra alba- Lagis koreni communities in its southern part (Marmin, 2013). The data after the end of the deposition phase (spring 2013 to spring 2014) were collected by sampling 17 stations in the Machu site (unpublished data). Species are grouped into 5 compartments: "omnivores/scavengers", "predators", "filter feeders", "selective deposit feeders", and "non-selective deposit feeders". Ash-free dry weights are converted to carbon contents using a conversion factor of 0.518 (Brey, 2001). P/B and Q/B ratios are taken from Le Loc'h (2004) and Brey (2001), and diet compositions from Rybarczyk and Elkaim (2003).

\subsubsection{Meiofauna}

The mean annual biomasses of meiofauna, as well as the $P / B$ and $Q / B$ ratios are obtained from the literature for a similar sediment habitat in the English Channel (Rybarczyk and Elkaim, 2003; Garcia et al., 2011).

\subsubsection{Zooplankton}

Mean annual biomasses of zooplankton are collected from another study focused on the Seine Estuary (Rybarczyk and Elkaim, 2003). The P/B and Q/B ratios are obtained from the literature (Wang, 2005).

\subsubsection{Bacteria}

The benthic bacterial biomasses, as well as $\mathrm{P} / \mathrm{B}$ and $\mathrm{Q} / \mathrm{B}$ ratios are taken from Chardy (1987) and McIntyre (1978) for a similar sediment habitat in the English Channel.

\subsubsection{Phytoplankton}

The phytoplankton biomass and P/B ratios are from Rybarczyk and Elkaïm (2003) and Hoch (1998), respectively. 
The mean annual biomass of dead organic matter is obtained from the formula of Pauly et al. (1993).

\subsection{Balancing the Ecopath model}

The models are considered balanced when the EE values of each group is lower than 1 (i.e. mass balance is reached) and no violations of energy balance are observed. We also check that physiological rates are within the known limits for each functional group: i) P/Q of 0.1-0.3 for consumers, and ii) respiration/biomass (R/B) ratios of 1-10 for fish groups. The EwE pedigree routine is used to quantify the input parameter uncertainties (Christensen and Walters, 2004). It helps to identify the least certain parameters that should be modified first to achieve mass balance. The balancing approach used here is top-down, starting with the top predator groups and moving down the food web to smooth out inconsistencies. When modifications of the data are required, diet compositions (DC) are modified first, and then the $P / B$ and $Q / B$ ratios. Biomasses (B) are considered as less uncertain, and are thus modified during the last step of the balancing process.

Biomasses of the small pelagic fish are left to be estimated by the model after setting their Ecotrophic Efficiency at 0.93. The estimated biomasses are higher than the input data first entered during model construction. This can be partly explained by the fact that the bottom-trawl deployed during the CSLN survey was not fully adapted to capture these species, the abundance of which is thus likely to be underestimated. The biomass of the meiofauna is also left to be estimated by the model after setting their Ecotrophic Efficiency at 0.97.

\subsection{Analysing ecosystem organization, major interactions and emergent properties}

For the two Ecopath models (before and after the dumping operations), the trophic level of each functional group is calculated from its diet composition matrix. It is computed as the weighted average of the trophic levels of its prey, with primary producers and non-living material being set at a trophic level of 1:

$$
T L_{j}=1+\sum_{i=1}^{N} D C_{j i} T L_{j} \quad \text { (Eq. 3) }
$$


Ecological Network Analysis (ENA) indices are calculated using the network analysis plug-in included in EWE (Christensen and Walters, 2004). The following ENA indices are adopted:

- The Total System Throughflow (T..) is calculated as the sum of all the flows in the food web. It characterizes the overall activity and measures the size of the ecosystem (Latham, 2006).

- The Transfer Efficiency (TE) is the fraction of total flows of each discrete trophic level that throughput into the next level (Lindeman, 1942).

- Finn's Cycling Index ( $\mathrm{FCl}$ ) gives the percentage of all flows generated by cycling (i.e. the percentage of carbon flowing in circular pathways) (Finn, 1980).

- The System Omnivory Index (SOI) is calculated as the average of the Ols of the individual group, weighted by the logarithm of each consumer intake (Pauly et al., 1993, Christensen and Walters, 2004). It is an indicator of the structure and complexity of the food web that measures how the interactions are distributed among trophic levels (Christensen and Walters, 2004). High values of SOI correspond to a web-like structure, whereas low values of SOI correspond to a chain-like structure (Libralato, 2008).

- The ascendency (A) is a measure of the system activity (Total System Throughput) linked to its degree of organization (Average Mutual Information; AMI) (Ortiz and Wolff, 2002). This index is related to the developmental status or maturity of an ecosystem (Ulanowicz, 1986).

- Relative redundancy $(\mathrm{R} / \mathrm{DC})$ measures the fraction of internal flows in proportion to total development capacity. It corresponds to an indicator of the inefficiency of the network (SaintBéat et al., 2013) as it measures the number of parallel trophic itineraries connecting the different trophic compartments (Rybarczyk and Elkaïm, 2003).

The Mixed Trophic Impact (MTI) routine is applied to evaluate the impacts of direct and indirect interactions in the food web. This analysis shows the theoretical effect that a slight increase in the biomass of one group would have on the biomasses of all the other groups in the system (Ulanowicz and Puccia, 1990). The Keystoneness Index is calculated for each functional group, to identify those groups having a high overall effect on the other groups compared to their relatively low biomass. Calculations are performed according to the index defined by Libralato et al. $(2005,2006)$. The Detritivory/Herbivory ratio $(D / H)$ is the ratio between detritivory flows (from detritus to trophic level II) and herbivory flows (from primary producers to trophic level II) (Ulanowicz, 1992). The ratio of biomass of fish groups to the biomass of invertebrate groups is also calculated. 
The calculated Pedigree index for the models is 0.5 .

\subsection{Structure and functioning of the ecosystem before dumping operations}

294

295

Phytoplankton is the dominant functional group in the biomass, representing $39.5 \%$ of the total living biomass of the system (Table 1). The other major groups of the system are benthic invertebrates, filter feeders (mostly composed of the Terebellidae Polychaete Lanice conchilega) and non-selective deposit feeders (mostly composed of the sea urchin Echinocardium cordatum), making up $22.6 \%$ and $17.6 \%$ of the living biomass, respectively.

The Trophic Level of the functional groups ranges from $T L=1$ for primary producers and detritus, as imposed by construction, to a maximum of 4.4 for cephalopods that can be thus considered as top predators in the area (Table 1). Demersal fish rank just below with a trophic level of 4.1. The omnivorous feeding mode of the functional groups, estimated by the omnivory index (OI), is comprised between 0.1 and 0.709 . The groups with the highest $\mathrm{OI}$ values are cephalopods ( $\mathrm{OI}=0.709$ ), followed by benthic invertebrate omnivores/scavengers $(\mathrm{OI}=0.439)$ and demersal fish $(\mathrm{OI}=0.435)$, while the most specialized group is made up of planktivorous fish $(\mathrm{OI}=0.0885)$.

The MTI analysis (Fig. 3) indicates that demersal fish exert a widespread influence on the trophic web, due to the wide diversity of prey items. In fact, demersal fish negatively affect benthic invertebrate selective deposit feeders, planktivorous fish and benthic-feeding fish. Other predators such as cephalopods, also feeding on these compartments, respond negatively to an increase of demersal fish biomass. The MTI analysis also shows that benthic invertebrate predators negatively affect benthic invertebrates (non-selective and selective deposit feeders, omnivores/scavengers). They also negatively affect cephalopods and benthic-feeding fish, which have some preys in common with benthic predators.

The keystoneness index is highest for zooplankton (-0.145), benthic invertebrate predators (0.196) and demersal fish (-0.201) (Fig. 4).

\subsection{Ecosystem structure and changes of functioning after dumping operations}

After the dumping operations, the phytoplankton remains the dominant functional group of the total living biomass of the system, followed by benthic invertebrates and filter feeders (Table 1). The biomass of demersal fish (dominated by the pouting Trisopterus luscus), benthic-feeding fish (dominated by the flatfish Pleuronectes platessa) and planktivorous fish (dominated by the mackerel 
Scomber scombrus) increases by factors of $4.7,8.4$ and 6 , respectively (Table 1 ). The biomasses of benthic invertebrate omnivores/scavengers (dominated by the decapod Liocarcinus marmoreus) and predators (dominated by the sea star Asterias rubens) also increase by factors of 3.3 and 3.5, respectively (Table 1). By contrast, cephalopods and benthic invertebrate non-selective deposit feeders show a strong decline with a $98 \%$ and $66 \%$ reduction in their biomass, respectively (Table 1 ). The biomass of cephalopods and benthic invertebrate filter feeders also decreases after the dumping operation. Results also indicate the presence of a new functional group after the dumping operations, i.e. piscivorous fish, but with a very low biomass of $0.0039 \mathrm{gC} \mathrm{m}^{-2}$ (Table 1). The ratio of fish biomass to invertebrate biomass increases approximately sevenfold between both periods (Machu After / Machu Before). This is related to the strong increase in fish biomass that rises by a factor of approximately 8 after the dumping operations, while invertebrate biomass remains relatively stable through time.

The Keystoneness patterns show variations between the two periods (Fig. 4). Before the dumping operations, zooplankton was the functional group with the highest keystoneness index, with benthic invertebrate predators occupying the second rank followed by demersal fish. However, after the dumping operations, the piscivorous fish became the functional group with the highest keystoneness $(0.003)$, followed by the zooplankton (0.141) and cephalopods (-0.167). Benthic invertebrate predators and demersal fish remain at a lower rank, since they occupy the fifth and the fourth rank, respectively.

Between the two periods, the total ecosystem activity (T..), representing the sum of all flows in the system, increases by $1.3 \%$ (Table 2). The System Omnivory index (SOI) increases by $13.34 \%$ (from 0.22 to 0.25 ) between the two periods, while Finn's Cycling Index (FCI) decreases by $16.4 \%$ (Table 2). The ascendency $(\mathrm{A})$ increases by $0.7 \%$. The relative redundancy and the detritivory/herbivory ratio $(D / H)$ remain stable between the two periods (Table 2). The transfer efficiencies (TE) show a similar pattern between the periods, decreasing as a function of TL in both models (Fig. 5).

The system overall EE (the percentage of total production consumed by predators) increases by $19.5 \%$ between the two periods (Table 1). For instance, the EE of Benthic invertebrate omnivores/scavengers, filter feeders and non-selective deposit feeders increases by a factor of 1.5, 3, and 6 , respectively (Table 1 ). 


\section{Discussion}

\section{1- Effects of dumping operations on the sediments}

The dumped muddy fine sand formed a conical pile at the MASED site and a wide and irregular elongated dump mound at the MABIO site; in both cases, a depression due to the settling of dredged material persisted at the sea bottom throughout the surveys (Marmin et al., 2016), this morphometry can provide a favourable habitat for demersal fishes. The superficial sediments at the MACHU site show a fining tendency with time due to the experimental deposition of estuarine sediments (with an effect limited to $500 \mathrm{~m}$ around the impacted stations), but the stations surrounding the MACHU site do not record any significant changes (Marmin et al., 2016). After deposition, during the year following the survey, a small proportion (5-20\%) of the accumulated material was lost, either due to erosion and transport away from the site, or due to consolidation. At the same time, a progressive recovery of the sea bed is suggested at some stations: the multimodal grain-size distribution reflects mixing of part of the dumped sands with shelf material (Marmin et al., 2016).

\section{2- Demersal fish and benthic response to dumping activities}

For demersal fish, the four years of monitoring reveal an attraction for, or at least a higher concentration of three flatfish species: Solea solea, Pleuronectes platessa and Limanda limanda at the experimental site of Machu during and after the deposit operations. More particularly, the study of demersal fish shows a high concentration of individuals belonging to these three flatfish species during the experimental dumping and up to 9 months after cessation for L. limanda and up to 27 months for $P$. platessa. The response to experimental dumping reflects a spatial differentiation, with an attractive effect over the entire experimental area or over only a part. The morpho-sedimentary changes induced by dumping therefore seem to create an attractive environment for L. limanda, S. solea and P. platessa (adult fish of a year). This may occur for trophic reasons, including the input of macrozoobenthos during dumping. The dumping operations generate a new source of food in the ecosystem. Possibly due to the biomass modifications, EE values (the percentage of production consumed by predators) of the whole ecosystem show an increase of $20.5 \%$. The macrozoobenthos provided by dumping could increase the fish predation.

For the benthic compartment, a small variation of biomass is observed between the different trophic groups. However, taxa diversity and changes in communities are perceptible during the experiment, as has been observed in several studies (Bolam et al., 2006; Ware et al., 2010). While 164 taxa are recorded at the Machu site, 102 taxa show a decrease in their abundance and 43 taxa are no 
longer sampled after dumping. Conversely, after dumping, 57 taxa show an increase in their abundance and 30 new taxa are recorded. This increase/decrease in abundance is the result of a community change. Before the dumping operation, there was a typical medium sand Nephtys cirrosa community characterized by the polychaetes (Magelona filiformis/johnstoni, Nephtys cirrosa) and amphipods (Megaluropus agilis, Urothoe elegans, etc.) found in the eastern part of the Bay of Seine (Marmin, 2013), in the eastern part of the English Channel (Prygiel, 1987) and in the southern North Sea (Desroy et al., 2002; Van Hoey et al., 2004). After dumping, the Machu site corresponded to a mix of the Nephtys cirrosa and Abra alba communities of medium and muddy fine sand (with the bivalves Phaxas pellucidus, Spisula subtruncata, and the polychaete Owenia fusiformis, etc.). The Abra alba community of the Bay of Seine shows the richest abundance and biomass for the European seas (Thiébaut et al, 1997; Dauvin and Desroy, 2005). Results show a faunal modification before/after the experiment, but no change is observed in the total biomass before/after dumping. Indeed, the biomass decrease in the benthic invertebrate non-selective deposit feeders is offset by an increase in the biomass of the benthic invertebrate omnivores/necrophages and predators.

The species established in the Nephtys cirrosa community at the Machu site are adapted to an unstable environment characterized by a strong hydrodynamic activity, with increased sedimentation and resuspension leading to natural sediment instability (Marmin, 2013). These species can tolerate sedimentation rates caused by anthropogenic activities such as dumping (see for example Newell et al., 1998; Roberts et al, 1998; Prevedelli et al., 2001; Bolam et al, 2016). Bolam and Rees (2003) showed that invertebrate recolonization in stable marine environments can take several years, whereas it takes place only on the order of several months in naturally disturbed environments (strong hydrodynamics, polyhaline habitats, etc.). In the case of naturally perturbed environments, the community structure is generally less complex and, as a result, ecological succession levels are lower, which ultimately leads to shorter recovery periods (Diaz, 1994). The medium sand Nephtys cirrosa community appears to have a great capacity for restoration after disturbance in relation to the annual recruitment of benthic macrofauna. After the dumping, the spring-summer recruitment of the dominant benthic species ( $A b r a$ alba-Lagis koreni muddy fine sand community, which shows a bentho-pelagic cycle) ensures a rapid increase in the abundance in the area impacted area by the deposition. This is in agreement with the high ranking of zooplankton in the keystoneness index, suggesting that the food web is bottom-up controlled. Moreover, adult migration coupled with a strong hydrodynamic regime, such as occurring with the bivalve Abra alba (Olivier et al., 1996, Marmin, 2003), also contributes to the recovery of the stressed environment (see Powilleit and Kube, 1999; Zajac et al., 1998). This adult migration demonstrates the important role of the areas around a disturbed site in macrofauna recovery. The presence of nearby non impacted areas provides a source of drifting migrating adults that leads to a much quicker recovery of the impacted site due to the juvenile recruitment (Zajac and Whitlatch 2001; 
Diaz, 1994). The important resilience of the Machu site is due to physical parameters: a particular hydrodynamic environment with strong tidal flow and flow currents faster than ebb currents, which maintain the ecosystem in a stressed state.

The Machu site seems to be a resilient ecosystem, which can be explained by the limited impacted area (500 $\mathrm{m}$ around the impacted station) and by the presence of a non-impacted zone serving as a reserve for the colonization of macrozoobenthic invertebrates on the impacted zone. This colonization is made possible by the drift of the post-larvae, juveniles and adults living near the impacted zone during a tidal cycle and on a large spatial scale (the whole community), as observed by Olivier et al (1996) in the Abra alba community of the eastern part of the Bay of Seine, including two benthopelagic cycle species with massive recruitment capacities: Owenia fusiformis and Pectinaria koreni (Thièbaut, 1994; Thièbaut et al., 1992). The resilience of an ecosystem impacted by dumping has also been studied in the Mediterranean Sea (Hermand, 2008). This author observed a colonization of cuttings in less than 6 months (with a specific richness higher than at the control stations) and a total restoration of the ecosystem in 18 months (Hermand, 2008).

\section{3- Strengths and drawbacks of model construction}

In this study, we have investigated the trophic web of the Machu site one year before and two years after the dumping operations. From a methodological point of view, the models were based on high quality source data as evidenced by the high value of the pedigree index and compared to the pedigree values distribution for pre-existing models (Morissette, 2007). In fact, the pedigree index (0.5) was in the highest part of the range (0.164 to 0.676 ) reported in Morissette (2007). In the majority of cases, biomasses were integrated and did not need to be estimated by the model. This was mostly due to the biomass data sources, which were obtained from local, highly replicated, and detailed samplings trough a Before-After-Control-Impact (BACI) approach from April 2010 to April 2014. In addition, the diet compositions of the fish species came from stomach content studies performed in the eastern English Channel.

The model developed in this study was atypical due to its intrinsic small spatial scale with one on the main drawbacks being the fact that the population dynamics and home range of mobile species vastly exceed the limits of the Machu site. As a partial solution, we consider trophic transfers outside the area of the Machu site for fish by setting import entries in the diet composition matrix. This limitation is common to all small-scale Ecopath models (e.g. marine protected areas or offshore wind farms (Albouy et al., 2010; Colléter et al., 2012; Valls et al., 2012; Raoux et al., 2017). 


\section{4- Changes in ENA indices related to stress}

Ecological Network Analysis indices are powerful tools because they can link system architecture to system functioning and can reveal emergent properties (Ulanowicz, 2004). These indices have been commonly used in coastal and marine systems to assess changes in their functioning in response to perturbations (Tomczak et al., 2013; Tecchio et al., 2015; Raoux et al., 2017) and as ecosystem health indicators (Bondavalli et al., 2006; Niquil et al., 2012; Niquil et al., 2014). In fact, several emergent properties of ecological functioning can change under stress (Mukherjeer et al., 2015; Tecchio et al., 2015).

In the present study, the ENA indices are calculated to analyse the status of the Machu site ecosystem as regards resisting stress. According to our models, one year of dumping operations appears to have a relatively limited impact on the structure and flow pattern of the local food web. In fact, only small variations between the two periods are revealed by a comparison of ENA indices (total ecosystem activity (T..), ascendency (A), Finn's Cycling Index (FCI), system omnivory index (SOI) and relative redundancy (R/DC) before and after the dumping operations.

Results show that the total activity of the Machu site ecosystem, as measured with T.., increased after the dumping operations. This could be partly explained by the sampling of a new fish compartment after the dumping operations, which led to an increase in fish diversity and complexity consequently favouring an increase of ecosystem activity (Baeta et al., 2011; Hall, 1994). Ascendency, which measures the developmental status or maturity of an ecosystem (Ulanowicz, 1986), also increased after the dumping operations. As an ecosystem matures, it goes through successive stages (Odum, 1969) associated with a shift from opportunist to specialist species (Walker and Salt 2006). According to Ulanowicz et al. (1997), the ascendance should increase as the system becomes more specialist. Moreover, these authors state that, on the contrary, ascendency is supposed to change and more particularly decrease if a system is affected by disturbance. Other authors agree with Ulanowicz et al. (1997), maintaining that low ascendency indicates a stressed or immature system (Ortiz and Wolff, 2002; Patricio et al., 2006; Baird et al., 2009). Our results suggest that the dumping operations will not act as a stress for the Machu site ecosystem which shows high resilience.

In a similar way, the decreasing trend in Finn's Cycling Index (proportion of all flows generated by cycling) tends to confirm that the ecosystem was not perturbed after the dumping operations. In fact, the $\mathrm{FCl}$ index is often considered as a possible indicator of stress, and an increase in recycling is usually interpreted as a response to stress (Odum, 1985; Scharler and Baird, 2005; Tecchio et al., 2015). Under stress, cycling can act as a buffer during perturbation and increase the ability of the system to resist changes (Saint-Béat et al., 2015). 
After the dumping operations, we observed an increase in SOI. This increase can be partly explained by the sampling of piscivorous fish, which led to a change in the system from a chain-like to a web-like structure. The SOI index has also been described as a relevant indicator of stress (Lobry et al., 2008; Selleslagh et al., 2012). As omnivory enhances flexibility of the system, more omnivorous systems are able to absorb perturbations and recover more rapidly afterwards (Fagan, 1997; Libralato, 2008). In addition, according to Fagan (1997), an increase in the degree of omnivory has a stabilizing role on the system. This index can be associated with the redundancy (Williams and Martinez, 2004). this index remained the same between the two periods, suggesting that the non-organized part of the system appears to remain at the same level. As with SOI, relative redundancy brings flexibility to the system by allowing reorganization in the case of disturbance (Ulanowicz, 2009).

Furthermore, the transfer efficiencies (TE) decreased in parallel with TL in the two sampling periods indicating that the compartments behave functionally in a similar way before and after dumping operations. In fact, Coll et al. (2009) observed that marine ecosystems undergoing a perturbation such as fishing activities showed breaks in the typical decreasing pattern of TE. These observations are in line with the results mentioned above, and suggest that the dumping operations act as a limited stress for the Machu site ecosystem which shows high resilience.

The ENA results from the Machu model before and after the dumping operations can be compared with other ecosystems studied with the same methodology (Ecopath) and located in the same biome such as the Seine Estuary (Rybarczyk and Elkaim, 2003; Tecchio et al., 2015). The ENA indices before and after the dumping operations are of the same order of magnitude as the other models developed in the Bay of Seine, suggesting no major trophic structural and functional shift after the dumping operations. This result can be explained by the fact that the Bay of Seine is historically characterized by a high level of human activities (pollution, transport, fishing, aquaculture, harbour development, aggregate extraction, sediment dredging and deposition) (Dauvin, 2015) which have led to an increase in resilience through time to face these multiple pressures.

\section{Conclusion,}

In this study, we use trophic modelling based on the analysis of emergent ENA properties to study a local stress (dumping operations during one year) on the Machu food web. Our results show a combination of changes in the food-web structure and functioning, but reveal the high resilience of the Machu site after a short dumping phase. This high resilience can be explained by the fact that this ecosystem is subject to regular natural physical perturbations and is historically characterized by a high level of human activities. In addition, our study only concerns the dumping of one million cubic metres 
extracted and dumped each year to ensure the access of GPMR (Marmin et al., 2016). More representative experiments need to be conducted to provide further information on the capacity of the ecosystem to resist dumping operations in the long-term. Following the $\mathrm{BACl}$ approach, such modelling studies will be carried out both during and at the end of the dumping operations which have a duration of ten years.

One major recommendation of the GPRM is to exploit the future dumping site with alternating strips (Marmin, 2013). The dumping site would be divided into strips oriented parallel to the current direction. The strips would be used by alternating a dumping phase with a recovery phase in order to promote biological recovery processes ensuring the colonization of dumped sediment and the restoration of benthic communities.

\section{Acknowledgements}

This study forms part of the doctoral research work of S. Marmin, funded by the ANRT (the Rouen harbour and the French State). The study was funded in part by the Agence des Aires Marines Protégées in the framework of the INDICLAP project (INdicateurs d'Impacts de CLAPages sur les habitats benthiques). We thank M. Navon, A. Baffreau and E. Plantive for their assistance during the campaigns and in the laboratory; C. Le Guen for her help in the first stages of the model construction and C. Garcia for the initial ecosystem analysis before Machu deposition. We thank Gwenola De Roton, Camille Hanin and Aurélien Berno for providing the fish data. The authors gratefully acknowledge the support of the Channel and Aid to Navigation Service, Grand Port Maritime de Rouen. The captains and crew of the research vessels Côtes de la Manche and the Celtic Warrior are thanked for their flexibility and assistance during the campaigns. The authors are also grateful to the referee for his very useful comments on the first version of the paper and M. Carpenter for revising the English style and grammar.

\section{References}

Albouy, C., Mouillot, D., Rocklin, D., Culioli J.-M., Le Loc'h F., 2010. Simulation of the combined effects of artisanal and recreational fisheries on a Mediterranean MPA ecosystem using a trophic model. Mar. Ecol. Prog. Ser. 412, 207-221 
Baeta, A., Niquil, N., Marques, J.C., Patrício, J., 2011. Modelling the effects of eutrophication, mitigation measures and an extreme flood event on estuarine benthic food webs. Ecol. Model. 222, 12091221.

Baird, D., Fath, B.D., Ulanowicz, R.E., Asmus, H., Asmus, R., 2009. On the consequences of aggregation and balancing of networks on system properties derived from ecological network analysis. Ecol. Model. 220, 3465-3471.

Boët, P., Léger, M., Le Pichon, C., 1999. Modélisation du compartiment piscicole : Test d'un modèle bioénergétique pour mieux cerner la biomasse piscicole d'un bief de la Seine. Rapport interne Cemagref, pp. 11

Bolam, S.G., Rees, H.L., 2003. Minimizing impacts of maintenance dredged material disposal in the coastal environment: a habitat approach. Environmental Management 32, 171-188.

Bolam, S.G., Rees, H.L., Somerfield, P., Smith, R., Clarke, K.R., Warwick, R.M., Atkins, M., Garnacho, E., 2006. Ecological consequence of dredged material disposal in the marine environment: A holistic assessment of activities around the England and Wales coastline. Mar. Poll. Bull. 52, 415-426.

Bolam, S.G., Barry, J., Bolam, T., Mason, C., Rumney, H.S., Thain, J.E., Law, R.J., 2011. Impacts of maintenance dredged material disposal on macrobenthic structure and secondary production. Mar. Poll. Bull. 62, 2230-2245.

Bolam, S.G., 2012. Impacts of dredged material disposal on macrobenthic invertebrate communities: a comparison of structural and functional (secondary production) changes at disposal sites around England and Wales. Mar. Poll. Bull. 64, 2199-2210.

Bolam, S.G., Mcllwaine, P.O., Garcia, C., 2016. Application of biological traits to further our understanding of the impacts of dedged material disposal on marine benthic assemblages. Mar. Poll. Bull. 105, 180-192.

Bondavalli, C., Bodini, A., Rossett, G., Allesina, S., 2006. Detecting stress at the whole-ecosystem level: the case of a mountain lake (Lake Santo, Italy). Ecosystems 9, 768-787.

Brey, T., 2001. Population Dynamics in Benthic Invertebrates. A Virtual Handbook. http://thomasbrey.de/science/virtualhandbook.

Cachera, M. 2013. Implications of morphological and functional traits for trophic relationships within fish communities and marine trophic network architecture. Thèse de doctorat de l'Université Sciences et Technologies de Lille, France. pp. 247

Chardy, P., 1987. Modèle de simulation du système benthique des sédiments grossiers du golfe normand-breton (Manche). Oceanol. Acta. 10, 421-434.

Christensen, V., Walters, C.J., 2004. Ecopath with Ecosim: Methods, capabilities and limitations. Ecol. Model. 172, 109-139. 
Christensen, V., Walters, C.J., Pauly, D., Forrest, R., 2008. Ecopath with Ecosim version 6 User Guide. Lensfest Ocean Futures Project, pp. 235.

Coll, M., Palomera, I., Tudela, S. 2009. Decadal changes in a NW Mediterranean Sea food web in relation to fishing exploitation. Ecol. Model. 220, 2088-2102.

Colléter, M., Gascuel, D.,Ecoutin, J.-M.,Tito de Morais, L., 2012. Modelling trophic flows in ecosystems to assess the efficiency of marine protected area (MPA), a case study on the coast of Sénégal. Ecol. Model. 232, 1-13.

Daly, H.I., Pierce, G.J., Santos, M.B., Royer, J., Cho, S.K., Stowasser, G., Robin, J.P., Henderson, S.M., 2001. Cephalopod consumption by trawl caught fish in Scottish and English Channel waters. Fish. Res. 52, 51-64.

Diaz, R.J., 1994. Response of tidal freshwater macrobenthos to sediment disturbance. Hydrobiologia $278,201-212$.

Dauvin, J.C., 2006. The Seine estuary, a highly developed area. Seine-Aval Special Issue, September 2006, North Atlantic Estuaries, Problems and Perspectives, pp. 27-32.

De Pierrepont, J.F., Dubois, B., Desormonts, S., Santos, M.B., Robin, J.P., 2005. Stomach contents of English Channel cetaceans stranded on the coast of Normandy. J. Mar. Biol. Assoc. UK. 85, 15391546.

Desroy, N., Warembourg, C., Dewarumez, J.M., Dauvin, J.C., 2002. Macrobenthic resources of the shallow soft-bottom sediments in the eastern English Channel and southern North Sea. J. Mar. Sci. $60,120-131$.

Fagan, W.F., 1997. Omnivory as a stabilizing feature of natural communities. Am. Nat. 150, 554-567.

Garcia, C., Chardy, P., Dewarumez, J.M., Dauvin, J.C., 2011. Assessment of benthic ecosystem functioning through trophic web modelling: the example of the eastern basin of the English Channel and the Southern Bight of the North Sea. Mar. Ecol. 32, 72-86.

Gentil, F., Cabioch, L., 1997. Les biocénoses subtidales macrobenthiques de la Manche, conditions écologiques et structure générale. In: Les biocénoses marines et littorales françaises des côtes Atlantique, Manche et Mer du Nord. Synthèse, menaces et perspectives, 28. Dauvin J.C. (ed). Museum National d'Histoire Naturelle, Paris, pp. 349

Hall, J.S., 1994. Physical disturbance and marine benthic communities: life in unconsolidated sediments. Oceanogr. Mar. Biol. Annu. Rev. 32, 179-239.

Harvey, M., Gauthier, D., Munro, J., 1998. Temporal changes in the composition and abundance of the macrobenthic invertebrate communities at dredged material disposal sites in the Anse à Beaufils, baie des Chaleurs, eastern Canada. Mar. Poll. Bull. 36, 41-55. 
Hermand, R., 2008. Réponses d'une communauté macrobenthique Méditerranéenne soumise à des apports sédimentaires allochtones naturels ou anthropiques. Université de la Méditerranée (AixMarseillle II), pp. 233

Hoch, T., 1998. Modélisation du réseau trophique pélagique et de la production primaire en Manche. Oceanol. Acta 21, 871-885.

Larsonneur, C., Bouysse, P., Auffret, J.P., 1982. The superficial sediments of the English Channel and its western approaches. Sedimentology 29, 851-864.

Latham, L.G., 2006. Network flow analysis algorithms. Ecol. Model. 192, 586-600.

Lindeman, R.L., 1942. The Trophic-Dynamic Aspect of Ecology. Ecology 23, 399-417.

Libralato, S., Coll, M., Santojanni, A., Solidoro, C., Arneri, E., 2005. Comparison between trophic models of protected and fishing areas for an ecosystem approach to fisheries in Adriatic Sea. ICES-CIEM International Council of the Exploration of the Sea. Annual Scientific Conference 11.

Libralato, S., Christensen, V., Pauly, D., 2006. A method for identifying keystone species in food web models. Ecol. Model. 195, 153-171.

Libralato, S., 2008. System Omnivory Index. Ecol. Ind. 4, 3472-3477.

Le Loc'h, F., 2004. Structure, fonctionnement, évolution des communautés benthiques des fonds meubles exploités du plateau continental Nord Gascogne. Thèse de Doctorat, Université de Bretagne Occidentale, Océanographie Biologique, Brest, France. pp. 379.

Lesourd, S., Lesueur, P., Brun Cottan, J.C., Garnaud, S., Poupinet, N., 2003. Seasonal variations in the characteristics of superficial sediments in a macrotidal estuary (the Seine inlet, France). Estuar. Coast. Shelf. Sci. 58, 3-16.

Lesourd, S., Lesueur, P., Fisson, C., Dauvin, J.C., 2016. Sediment evolution in the mouth of the Seine estuary (France): a long-term monitoring during the last 150 years. C. R. Geosci. 348, 442-450.

Lobry, J., David, V., Pasquaud, S., Lepage, M., Sautour, B., Rochard, E., 2008. Diversity and stability of an estuarine trophic network. Mar. Ecol. Prog. Ser. 358, 13-25.

Mackinson, S., Daskalov, G., 2007. An ecosystem model of the North Sea to support an ecosystem approach to fisheries management: description and parameterisation. Sci. Ser. Tech. Rep. CEFAS pp. 142.

Marmin, S., 2013. Impacts biosédimentaires des expérimentations de clapages en baie de Seine sur la communauté des sables moyens propres à Nephtys cirrosa. Thèse de Doctorat, Terre Solide et Enveloppes Superficielles, Université de Caen Basse-Normandie, France, pp. 249

Marmin, S., Dauvin, J.C., Lesueur, P., 2014. Collaborative approach for the management of harbourdredged sediment in the Bay of Seine (France). Ocean Coast. Manag. 102, 328-339. 
Marmin, S., Patrick Lesueur, P., Dauvin, J.C., Samson, S., Tournier, P., Gallicher Lavanne, A., DubrulleBrunaud' C., Thouroude, C., 2016. An experimental study on dredge spoil of estuarine sediments in the Bay of Seine (France): a morpho-sedimentary assessment. Cont. Shelf Res. 116, 89-102.

McIntyre, A.D., 1978. The benthos of the western North Sea.Rapp. P. Réun. Cons. Int. Explor. Mer 172, 405-417.

Messieh, S.N., Rowell, T.W., Peer, D.L., Cranford, P.J., 1991. The effects of trawling, dredging and ocean dumping on the eastern Canadian continental shelf seabed. Cont. Shelf Res. 11, 1237-1263.

Morissette, L., 2007. Complexity, Cost and Quality of Ecosystem Models and Their Impact on Resilience: A Comparative Analysis, with Emphasis on Marine Mammals and the Gulf of St. Laurence Zoology. University of British Columbia, Vancouver BC, Canada, pp. 278

Mukherjee, J., Scharler, U.M., Fath, B.D, Ray, S., 2015. Measuring sensitivity of robustness and network indices for an estuarine food web model under perturbations. Ecol. Model. 306, 160-173

Newell, R.C., Seiderer, L.J., Hitchcock, D.R., 1998. The impact of dredging works in coastal waters: A review of the sensitivity to disturbance and subsequent recovery of biological resources on the sea bed. Oceanography and Marine Biology: An Annual Review 36, 127-178.

Niquil, N., Baeta, A., Marques, J.C., Chaalali, A., Lobry, J., Patrício, J., 2014. Reaction of an estuarine food web to disturbance: Lindeman's perspective. Mar Ecol Prog Ser. 512, 141-154.

Niquil, N., Chaumillon, E., Johnson, G.A., Bertin, X., Grami, B., David, V., Bacher, C., Asmus, H., Baird, D., Asmus, R., 2012. The effect of physical drivers on ecosystem indices derived from ecological network analysis: comparison across estuarine ecosystems. Estuar. Coast. Shelf Sci. 108, 132-143. Odum, E.P., 1969. The strategy of ecosystem development. Science 164, 262-270.

Odum, E.P. 1985. Trends expected in stressed ecosystems. Bioscience 35, 419-422.

Ortiz, M., Wolff, M., 2002. Trophic models of four benthic communities in Tongoy Bay (Chile): comparative analysis and preliminary assessment of management strategies. J. Exp. Mar. Bio. Ecol. 268, 205-235.

Olivier, F., Vallet, C., Dauvin, J.C., Retière, C., 1996. Drifting in post-larvae and juveniles in an Abra alba (Wood) community of the eastern part of the Bay of Seine (English Channel). J. Exp. Mar. Biol. Ecol. 199, 89-109.

Pauly, D., Soriano-Bartz, M., Palomares, M.L., 1993. Improved construction, parameterization and interpretation of steady-state ecosystem models. In: Christensen, V., Pauly, D. (Eds.), Trophic Models of Aquatic Ecosystems. ICLARM Conf. Proc. 26, 1-13.

Polovina, J.J., 1984. Model of a coral reef ecosystem. I. The ECOPATH model and its application to French Frigate Shoals. Coral Reefs. 3, 1-11.

Prygiel, J., 1987. Etude du peuplement à Ophelia borealis et de l'annélide Nephtys cirrosa (Ehlers 1868) en Manche orientale et en Mer du Nord occidentale. Thèse de doctorat, Université de Lille, pp. 
Powilleit, M., Kube, J., 1999. Effects of severe oxygen depletion on macrobenthos in the Pomeranian Bay (southern Baltic Sea): a case study in a shallow, sublittoral habitat characterized by low species richness. J. S. Res. 42, 221-234.

Prevedelli, D., Simonini, R., Ansaloni, I., 2001. Relationship of nonspecific commensalisms in the colonization of the deep layers of sediment. J. Mar. Biol. Assoc. U. K. 81, 897-901.

Raoux, A., Tecchio, S., Pezy, J.P., Degraer, S., Wilhelmsson, D., Cachera, M., Ernande, B., Lassalle, G., Leguen, C., Grangeré, K., Le loch, F., Dauvin, J.C., Niquil, N., 2017.Benthic and fish aggregation inside an offshore wind farm: Which effects on the trophic web functioning? Ecol. Indic. 72, 3346.

Roberts, R.D., Gregory, M.R., Foster, B.A., 1998. Developing an efficient macrofauna monitoring index from an impact study - a dredge spoil example. Mar. Pollut. Bull. 36, 231-235.

Rybarczyk, H., Elkaïm, B., 2003. An analysis of the trophic network of a macrotidal estuary: The Seine Estuary (Eastern Channel, Normandy, France). Estuar. Coast. Shelf Sci. 58, 775-791.

Saint-Béat, B., Dupuy, C., Bocher, P., Chalumeau, J., De Crignis, M., Fontaine, C., Guizien, K., Lavaud, J., Lefebvre, S., Montanié, H., Mouget, J.L., Orvain, F., Pascal, P.Y., Quaintenne, G., Radenac, G., Richard, P., Robin, F., Vézina, A.F., Niquil, N., 2013. Key Features of Intertidal Food Webs That Support Migratory Shorebirds. PLoS One 8, 1-17.

Saint-Béat, B., Baird, D., Asmus, H., Asmus, R., Bacher, C., Pacella, S.,R., Johnson, G.,A., David, V., Vézina, A.F., Niquil, N. 2015. Trophic networks: How do theories link ecosystem structure and functioning to stability properties? A review. Ecol. Ind. 52, 458-471.

Salomon, J.C., Breton, M., 1991. Courants résiduels de marée dans la Manche. Oceanol. Acta 11, 4753.

Salomon, J.C., Breton, M., 1993. An atlas of long term currents in the Channel. Oceanol. Acta 16, 439448.

Sanchez, F., Olaso, I., 2004. Effects of fisheries on the Cantabrian Sea shelf ecosystem. Ecol. Model. 172, 151-174.

Scharler, U.M., Baird, D., 2005. A comparison of selected ecosystem attributes of three South African estuaries with different freshwater inflow regimes, using network analysis. J. Mar. Syst. 56, 283308.

Selleslagh, J., Lobry, J., N'Zigou, A.R., Bachelet, G., Blanchet, H., Chaalali, A., Sautour, B., Boët, P., 2012. Seasonal succession of estuarine fish, shrimps, macrozoobenthos and plankton: Physico-chemical and trophic influence. The Gironde estuary as a case study. Estuar. Coast. Shelf Sci. 112, 243-254. 
Smith, S.D.A., Rule, M.J., 2001. The Effects of Dredge-Spoil Dumping on a Shallow Water Soft-Sediment Community in the Solitary Islands Marine Park, NSW, Australia. Mar. Pollut. Bull. 42(11), 10401048.

Tecchio, S., Tous Rius, A., Dauvin, J.C., Lobry, J., Lassalle, G., Morin, J., Bacq, N., Cachera, M., Chaalali, A., Villanueva, C.M., Niquil, N., 2015. Is ecological status of transitional water ecosystems linked to a mosaic of food-web emergent properties? Ecol. Model. 312, 91-101.

Tecchio, S., Chaalali, A., Raoux, A., Tous Rius, A., Lequesne, J., Girardin, V., Lassalle, G., Cachera, M., Riou, P., Lobry, J., Dauvin, J.C., Niquil, N., 2016. Evaluating ecosystem-level anthropogenic impact in a naturally stressed transition environment: the case of the Seine estuary; Ecol. Ind. 61, 833845.

Thiébaut, E., Cabioch, L., Dauvin, J.C., Retière, C., Gentil, F., 1997. Spatio-temporal persistance of the Abra alba-Pectinaria koreni muddy-fine sand community of the eastern bay of Seine. J. Mar. Biol. Assoc. U. K. 77, 1165-1185.

Tomczak, M.T., Heymans, J.J., Yletyinen, J., Niiranen, S., Otto, S.A., Blenckner, T., 2013. Ecological network indicators of ecosystem status and change in the Baltic Sea. PLoS ONE 8, e75439

Ulanowicz, R.E., 1986. Growth and Development: Ecosystems Phenomenology. Springer-Verlag, New York

Ulanowicz, R.E., Puccia, C., 1990. Mixed trophic impacts in ecosystems. Coenoses 5, 7-16.

Ulanowicz, R.E., Abarca-Arenas, L., G., 1997. An informational synthesis of ecosystem structure and function. Ecological Modelling 95: 1-10. J. Des. Nat. Ecodyn. 42, 83-96.

Ulanowicz, R.E., 2004. Quantitative methods for ecological network analysis.Comput. Biol. Chem. 28, 321-339.

Ulanowicz, R.E., 2009. The dual nature of ecosystem dynamics. Ecol. Model. 220, 1886-1892.

Valls, A., Gascuel, D., Guénette, S., Francour, P., 2012. Modeling trophic interactions to assess the effects of a marine protected area: case study in the NW Mediterranean Sea. Mar. Ecol. Prog. Ser. 456, 201-214.

Van Dolah, F., Calder, D.R., Knott, D.M., 1984. Effects of dredging and open-water disposal on benthic macroinvertebrates in a South Carolina estuary. Estuaries 7, 28-37.

Van Hoey, G., Degraer, S., Vincx, M., 2004. Macrobenthic community structure of soft bottom sediments at the Belgian Continental Shelf. Estuar. Coast. Shelf Sci. 59, 599-613.

Wang, X.Z., 2005. Variations a court-terme de la faune planctonique et suprabenthique en baie de Seine dans la zone sous influence d'apports d'eau douce en conditions printanieres. Lille, Universite des Sciences et Technologies de Lille. pp. 417

Ware, S., Bolam, S.G., Ress, H.L., 2010. Impact and recovery associated with the deposition of capital 
dredgings at UK disposal sites: Lessons for future licensing and monitoring. Mar. Pollut. Bull. 60, 79-90.

766 Wilber, D.H., Clarke, D.G., Rees, S.I., 2007. Responses of benthic macroinvertebrates to thin-layer disposal of dredged material in Mississippi Sound, USA. Mar. Pollut. Bull. 54, 42-52.

768 Williams, R.J., Martinez, N.D., 2004. Limits to trophic levels and omnivory in complex food webs: theory and data. Am. Nat. 163, 458-468.

770

Witt, J., Schroeder, A., Knust, R., Azntz, W.E., 2004. The impact of harbour sludge disposal on benthic macrofauna communities in the Weser estuary. Helgoland Mar. Res. 58, 117-128

Zajac, R.N., Whitlatch, R.B., Thrush, S.F., 1998. Recolonization and succession in soft-sediment infaunal communities: the spatial scale of controlling factors. Hydrobiologia 375/376, 227-240. 


\section{Figure captions}

778

779 Fig. 1. Location of the existing Octeville and Kannick as well as the future Machu dumping sites in the eastern part of the Bay of Seine, with outlines of the Natura 2000 site and marine harbour waiting areas.

782

Fig. 2. Flows and biomasses of the ecosystem before the dumping operations

Fig. 3. Mixed Trophic Impact (MTI) analysis performed on the trophic web before dumping operations. Overall impacts are represented as negative (black circles) or positive (white circles).

Fig. 4. Keystoneness index calculated for the two Ecopath models (before and after dumping operations; Machu Before model is shown in blue and Machu After scenario in green). The size of the circles is proportional to the functional group biomass.

791

Fig. 5. Transfer efficiencies for discrete trophic levels used in the two Ecopath models (before and after dumping operations; Machu Before model is shown in black and Machu After scenario in grey). 
Table 1

795 Biomass values, production to biomass ratios (P/B), consumption to biomass ratios (Q/B), Ecotrophic

796 Efficiencies (EE) and trophic level (TL) before and after the dumping operations.

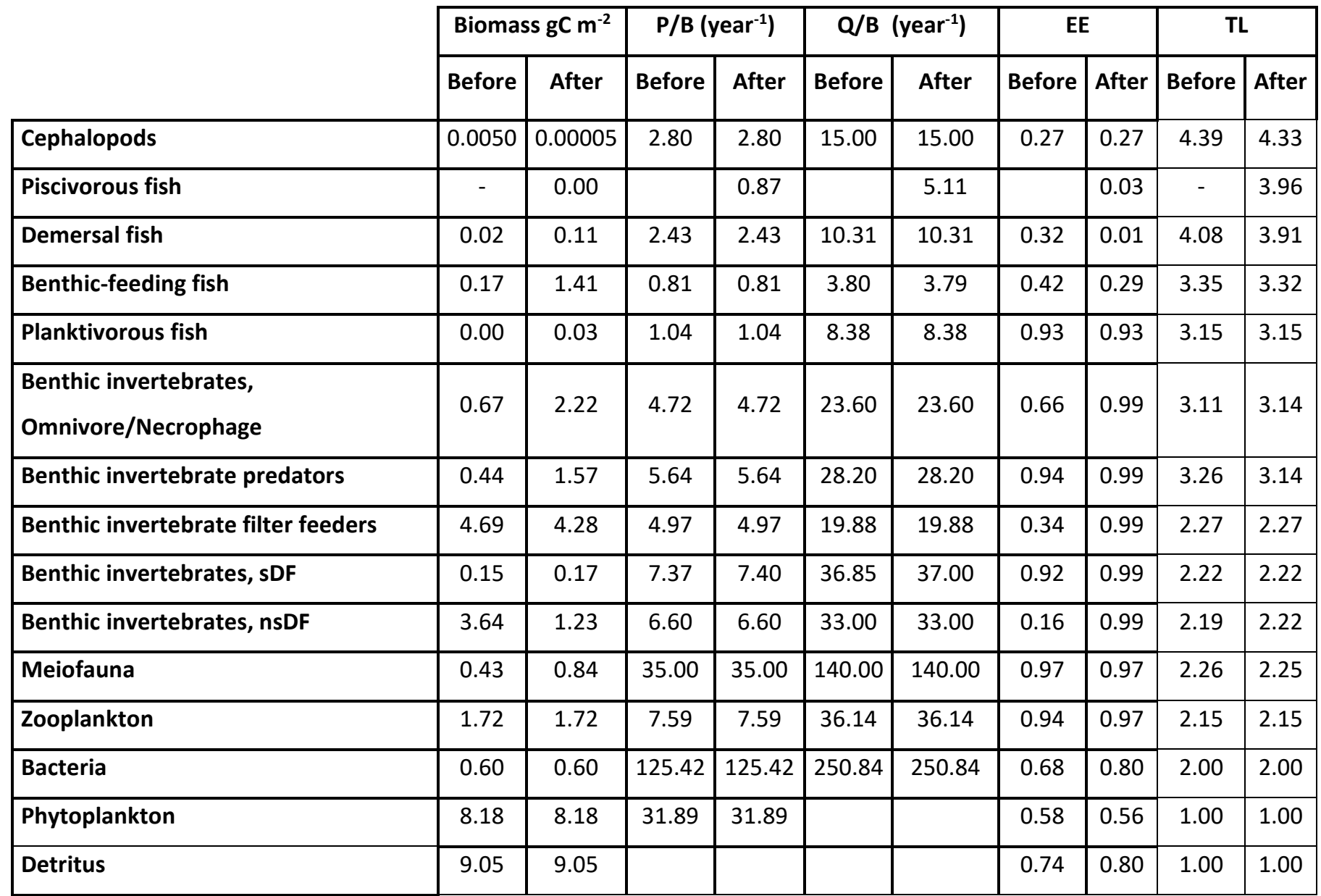

798

799

800 
802 ENA indices for the two models before and after the dumping operations. The Total System 803 Throughput ( $\mathrm{T} . ., \mathrm{gC} \mathrm{m}^{-2}$ year $\left.^{-1}\right)$ is calculated as the sum of all the flows in the food web. Finn's Cycling 804 Index ( $\mathrm{FCl})$ gives the percentage of all flows generated by cycling. The Ascendency $(\mathrm{A})$ is a measure of 805 the system activity (Total System Throughput) linked to its degree of organization (Average Mutual 806 Information) and is expressed in $\mathrm{gC} \mathrm{m}^{-2}$ year-1. The System Omnivory Index (SOI) is calculated as the 807 average of the Ols of the individual group, weighted by the logarithm of each consumer intake. The 808 Relative redundancy (R/DC) measured the fraction of internal flows as a proportion of total 809 development capacity

810

\begin{tabular}{|c|c|c|}
\hline ENA & Before & After \\
\hline T.. & 1130.13 & 1144.76 \\
\hline FCl & 11.82 & 9.88 \\
\hline Ascendance & 1129.90 & 1137.70 \\
\hline SOI & 0.22 & 0.25 \\
\hline R/DC & 0.59 & 0.59 \\
\hline
\end{tabular}


813 Table 3. General system statistics and ENA indices for the Machu models compared to values obtained 814 for similar systems. The Total System Throughput (T.., $\mathrm{gC} \mathrm{m}^{-2}$ year $\left.^{-1}\right)$ is calculated as the sum of all the 815 flows in the food web. The Ascendency (A) is a measure of the system activity (Total System 816 Throughput) linked to its degree of organization (Average Mutual Information) and is expressed in gC $\mathrm{m}^{-2}$ year ${ }^{-1}$. Finn's Cycling Index ( $\mathrm{FCl}$ ) gives the percentage of all flows generated by cycling. The System

818 Omnivory Index ( $\mathrm{SOI}$ ) is calculated as the average of the Ols of the individual group, weighted by the logarithm of each consumer intake.

820

\begin{tabular}{|c|c|c|c|c|c|}
\hline Ecosystems & T.. & A & FCI & SOI & Reference for Ecopath models \\
\hline Seine estuary & 3603.22 & 3944.3 & 16.1 & 0.11 & Rybarczyck and Elkaim, 2003 \\
\hline Seine estuary & $4584.92-1161.05$ & $1442.6-6058.6$ & $3.65-20.65$ & $0.160-0.193$ & Tecchio et al., 2015 \\
\hline Machu Before & 1130.13 & 1129.90 & 11.82 & 0.22 & This study \\
\hline Machu After & 1144.76 & 1137.7 & 9.88 & 0.25 & This study \\
\hline
\end{tabular}


Figure 1;

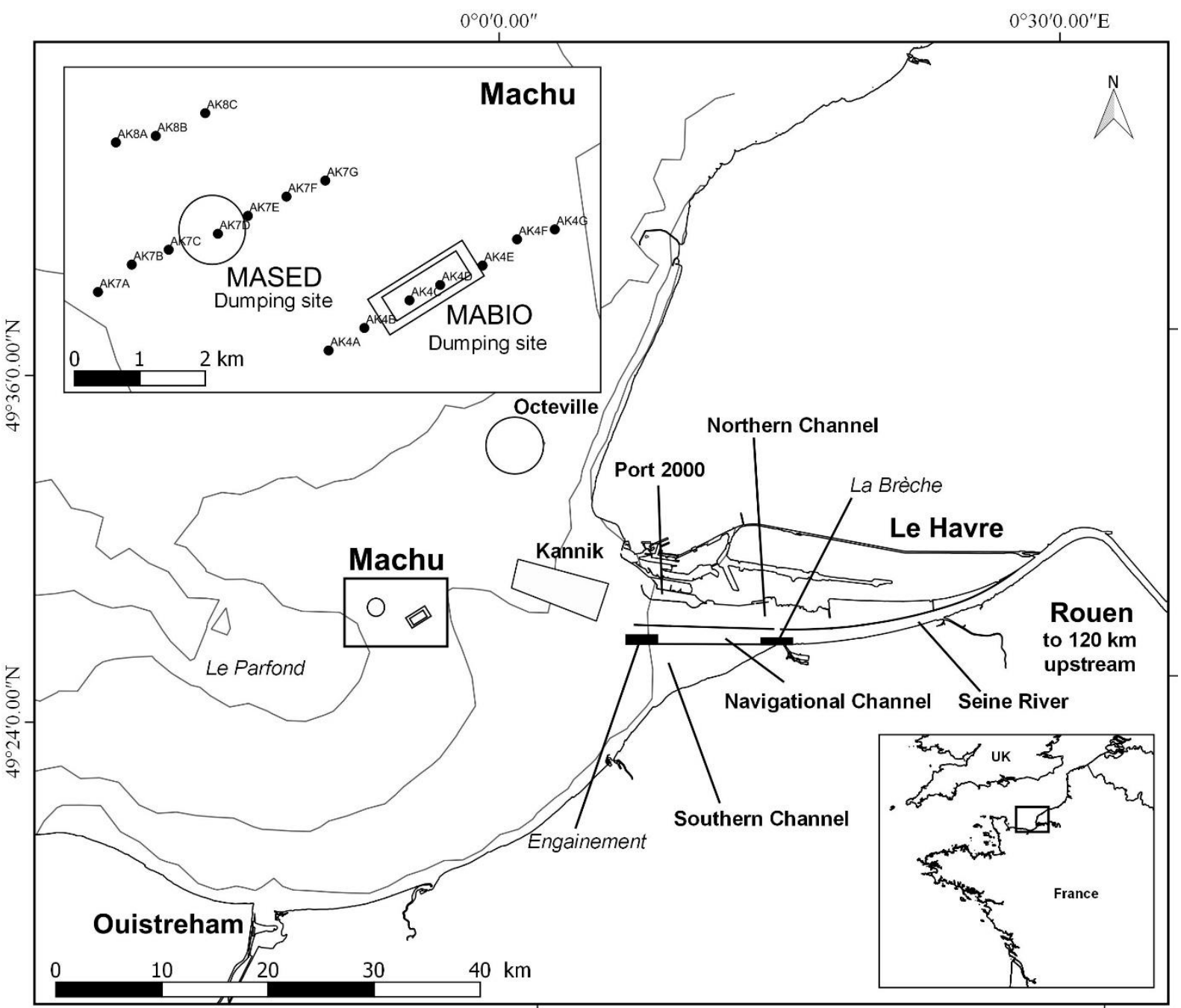

824

825

826 [Correction on figure: engainement $\rightarrow$ channel entry] 
5

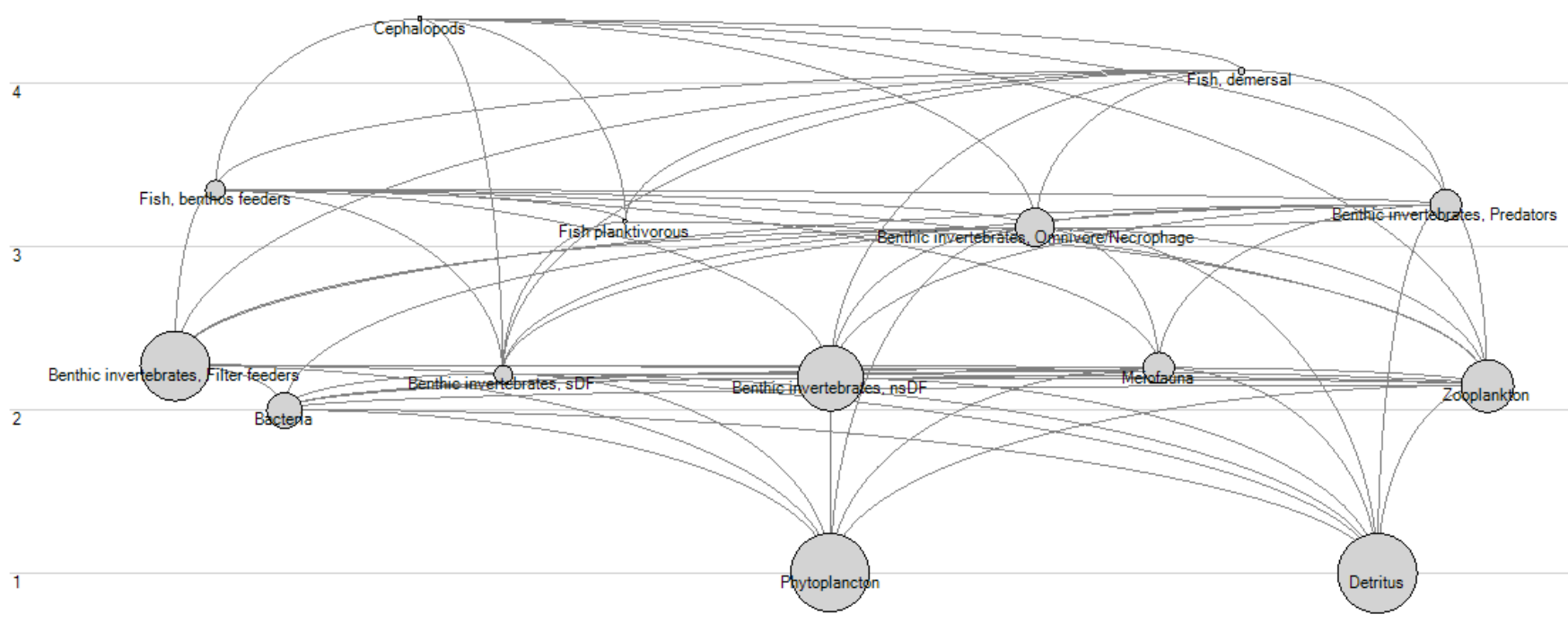


Impacted group

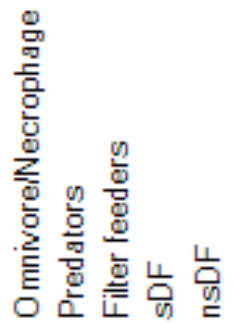

() Positive

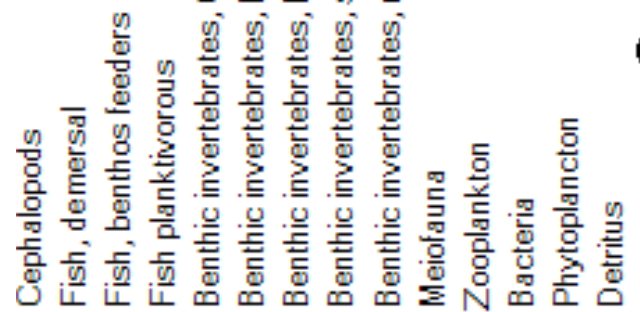

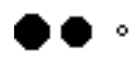

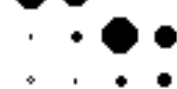

C Negative

\section{Cephalopods}

Fish, demersal

Fish, benthos feeders

Fish planktivorous

Benthic invertebrates, Omnivore/Necrophage

$++_{+}+0_{+}$, . Benthic invertebrates, Predators

- $\bullet++\bullet+\bullet$ Benthic invertebrates, Filter feeders

Benthic invertebrates, sDF

. ${ }^{\circ}+\bullet^{+}, .+\bullet \bullet \bullet,+$ Benthic invertebrates, nsDF

. . . + + • $\bullet+$. Meiofauna

( + . . * $\bullet$ Zooplankton

- Bacteria

$+0$

- Phytoplancton

$\circ \circ \cdot \circ \cdot$ Detritus 


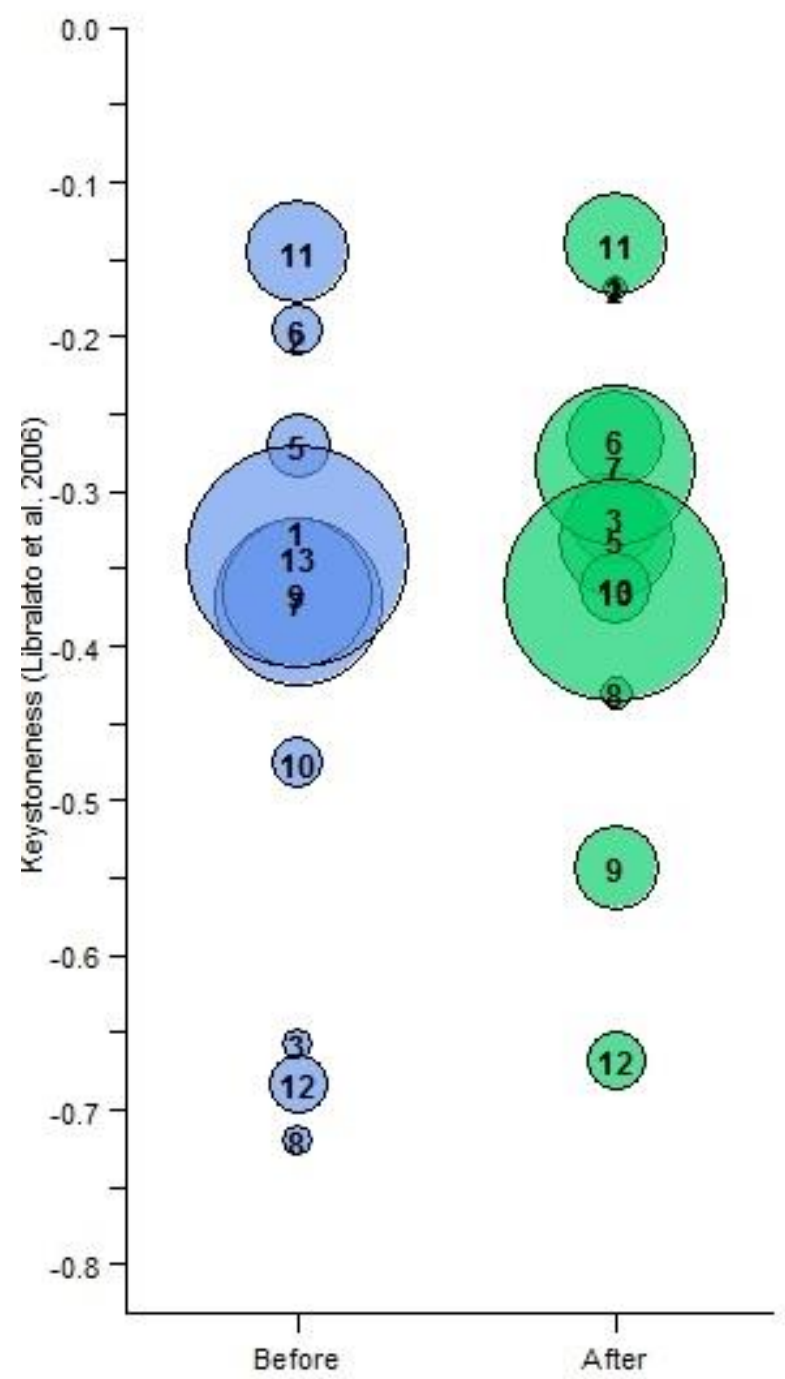

1 - Cephalopods

2 - Fish, demersal

3 - Fish, benthos feeders

5 - Benthic invertebrate, Omnivore/Necrophage

6 - Benthic invertebrate, Predators

7 - Benthic invertebrate, Filter feeders
8 - Benthic invertebrate, sDF

9 - Benthic invertebrate, nsDF

10 - Meiofauna

11 - Zooplankton

12 - Bacteria

13 - Phytoplancton 
Figure 5.

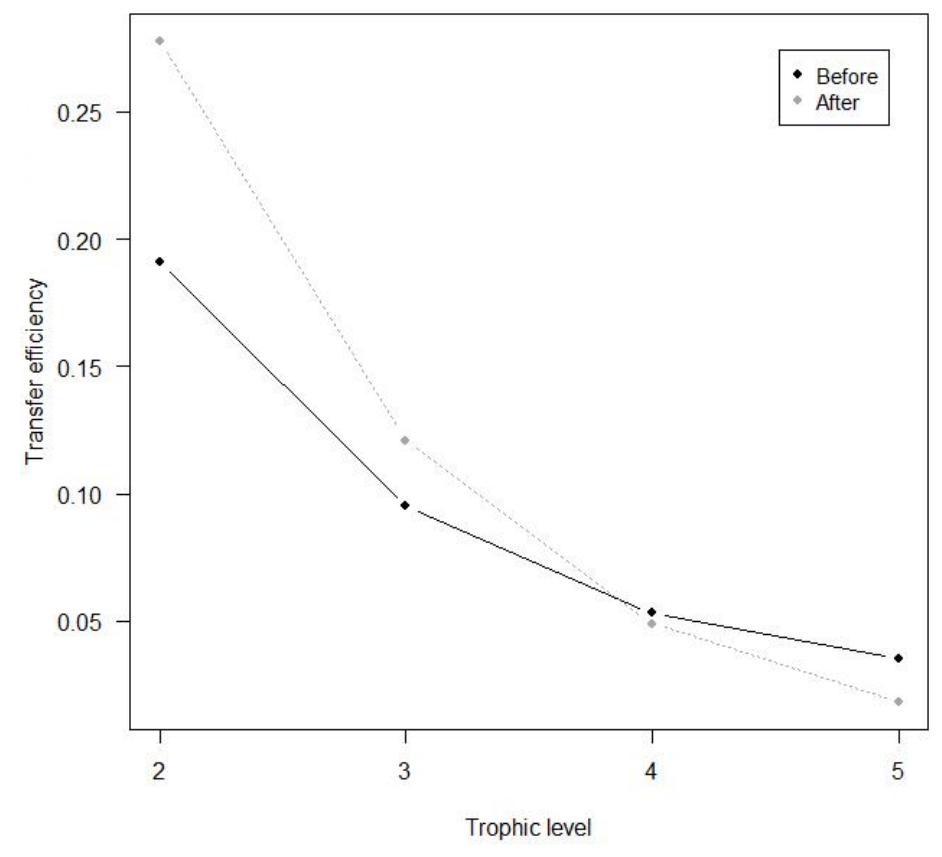

833 